\title{
Effect of Pollination Methods and Pollen Dilution on Some Chemical Constituents of Fard Dates at Different Stages of Fruit Development
}

\author{
Mahdi Osman El-Mardi ${ }^{1}$, Sghaier Naji Labiad ${ }^{2}$. \\ Evangeline Consolacion ${ }^{1}$ and Khidir M. Addelbasit ${ }^{3}$.
}

I Department of Plant Sciences, College of Agriculture,

2 Department of Agric. Mechanization, College of Agriculture,

3 Department of Mathematics, College of Sciences and Computing,

Sultan Qaboos University, Muscat, Oman.

\section{ABSTRACT :}

Date palms of the Fard cultivar, 10-11 years old, were pollinated by three methods : traditional (LBR), hand duster (HAND) and motorized duster (MAC). Pollen spread by the dusters was diluted with wheat flour at 1:5, 1:7 and 1:9 ratios. Sugars, pectin and titrable acidity were determined at the five developmental stages (Hababok, Kimri, Bisir, Rutab and Tamr) during 1991 and 1992. Fruits produced by the different treatments showed no significant difference in any of the tested constituents during the Kimri stage. In 1991, LBR Bisir fruits contained significantly higher total and reducing sugars than HAND and MAC fruits. In 1992 LBR Hababok and Tamr fruits contained higher titrable acidity and sucrose, respectively. High pectin content and sucrose contents in 1992 LBR fruits were associated with delayed maturation. Pollen dilution had a more pronounced effect than pollination methods. Fruits produced in 1991 by higher pollen concentration had higher sucrose contents, indicating more pectinase than invertase activity. Pollen diluted to 1:5 ratio produced fruits with higher reducing sugars than those produced by 1:9, whereas the latter produced fruits with the highest sucrose contents regardless of the pollination method employed. Significant differences in the amounts of chemical constituents during any of the developmental stages in succesive years suggested that their production followed an alternating phenomenon. Reduction in moisture, sucrose, pectin, titrable acidity and increase in total and reducing sugars indicate maturation of Fard dates. 
Fard dates can be classified of the soft type because reducing sugars dominate sucrose throughout their development stages.

Key words : Alternation, Mechanization, Pollination, Pollen dilution.

\section{INTRODUCTION}

There is a growing need for techiques which make date palm pollination more effective and economical. Traditional methods which involve climbing the palm to place a limited number of staminate strands in each pistillate spadix has become costly due to the lack of skilled labor. Young farmers consider it very tiresome, dangerous and little rewarding. Hence fewer farmers are keen to acquire the skills needed or to consider it as their future occupation. Faced with such situation, palm growers considered mechanized pollination as an alternative. Since the fifties, devices ranging from simple dusters to airplanes have been used to place pollen into the spadix (Monceiro 1950, Alexander 1952, Preston 1964, 1965). However, most of such devices cannot be used in the Middle East countries due to the special planting patterns inside the palm orchards (high trees density, multiple cropping system), high cost of the equiqment, and necessary operating and maintenance skills. Various adjustments are required to adapt these devices to suit specific cultivars and local production environments in order to reduce any negative effect they might have on the physical or chemical characteristics (sugars, pectin, acidity, fruit set, etc...) of the fruits. Such adjustments may include : type of equipment, amount of pollen to be applied and timing of pollination.

Chemical changes that occur in the date fruit throughout its developmental stages received a great deal of attention as a mean of standrdization and characterization of cultivars. Research of this concern has been undertaken in several countries where dates constitute a major crop (Mohamed et al. 1983, Yousif et al. 1982, Shabana et al. 1975 in Iraq; Sawaya et al. 1982, Hussein and El-Zaid 1978 in Saudi Arabia; Rajab et al. 1956 in Egypt and Ismail et al. 1986 in Lybia). However, reports on the effects of pollination method and pollen dilution on the chemical constituents of the date fruits are few in number. Shehata et al. 1986, reported that significant differences in total soluble solids, total reducing and non-reducing sugars occurred as a result of pollen dilution. 
The present research investigates the effect of three different pollination methods on selected chemical charcteristics of the Fard date at their various stages of development. It is intended to identify an appropriate pollination technique for the Fard cultivar, which dominates date processing in the Sultanate of Oman.

\section{MATERIALS AND METHODS}

Twenty-eight palm trees of the Fard cultivar, 10 years old, were randomly selected at the Nizwa Date Factory orchard. No consideration was given to the number of leaves or spardixes per palm, assuming that alternate bearing effect will be avoided by the 3rd year of the experiment. In this study pollination was carried out by 3 methods :

1. Traditional (LBR): a skilled local labor was hired to insert 3 male strands (Khory cultivar) in an inverted position inside each of the pistillate spadixes.

2. A hand operated duster (HAND), manufactured locally by Engine Engineering Co. in collaboration with the Ministry of Agriculture and Fisheries Wealth (Oman), was used to spray female flowers with pollen. The duster included a small piston pump connected to a reservoir and mounted on a set of aluminium pipes each 3 metres long. The pump is operated by compression and release of a small spring connected to the piston.

3. A motorized duster (MAC) was used to spray female flowers with pollen carried by a stream of pressurized air. The duster was developed in Iraq and adapted to the local working conditions by the Department of Agricultural Mechanization at the Sultan Qaboos University, (Oman). It included a small air compressor, operated by a two stroke gasoline engine, a 10 liter pressurized air storage tank, a sprayer gun, and a set of plastic pipes each 1.5 metres long. A hand valve is used to release pressurized air.

In the two mechanized operations, pollen was mixed with fine wheat flour at the ratios 1:5, 1:7 and 1:9. Three to 5 milligrams of 
pollen-flour mixture were applied to each spadix 4 times per season. Early and late appearing spadixes were pollinated at weekly intervals, whereas for those appearing in the middle of the flowering season, it was found necessary to shorten the interval to 3 or 4 days. In 1991, pollination started on 21 February and was completed on 10 March. In 1992, pollination started late (12 March) because of cold weather and was completed on 10 April. Fruit samples were taken from each palm to cover the five developmental stages (6 strands of Hababok and 4 of each of the other stages). The various samples were harvesed as follows :

1991

1. Hababok

2. Kimri

3. Bisir

4. Rutab

5. Tamr
IS Murch

S May

5 June

16 July

22 September
1992

20 April

24 May

25 June

13 July

21 September

Collected samin'es were placed in polyethylene bags and kept in ice until they were stored in a freezer $\left(-19^{\circ} \mathrm{C}\right)$ pending analysis.

Moisture, total sugar, reducing sugars and sucrose percentages were determined according to $\triangle O$ OSC 1984, pectin according to the procedure recommended by L.ess 1975 and titrable acidity according to AOAC 1966. Sugar, pectin and acidity were then calculated on dry weight basis. The results were statistically analyzed according to a completely randomized design (CRD) with four replications. Each treatment included one palm.

\section{RESULTS AND IISCUSSION}

\section{Changes in the Chemical Composition of Fard Fruits During the Five Developmental Stages :}

Data concerning these changes are shown in Table (1). Average values of the 1991 and 1992 results are presented.

a. Moisture : Moisture was higher in Kimri than in Hababok but it progressively decreased as the fruits matured from Kimri onwards. The highest reduction was between Rutab and Tamr (38\%) 


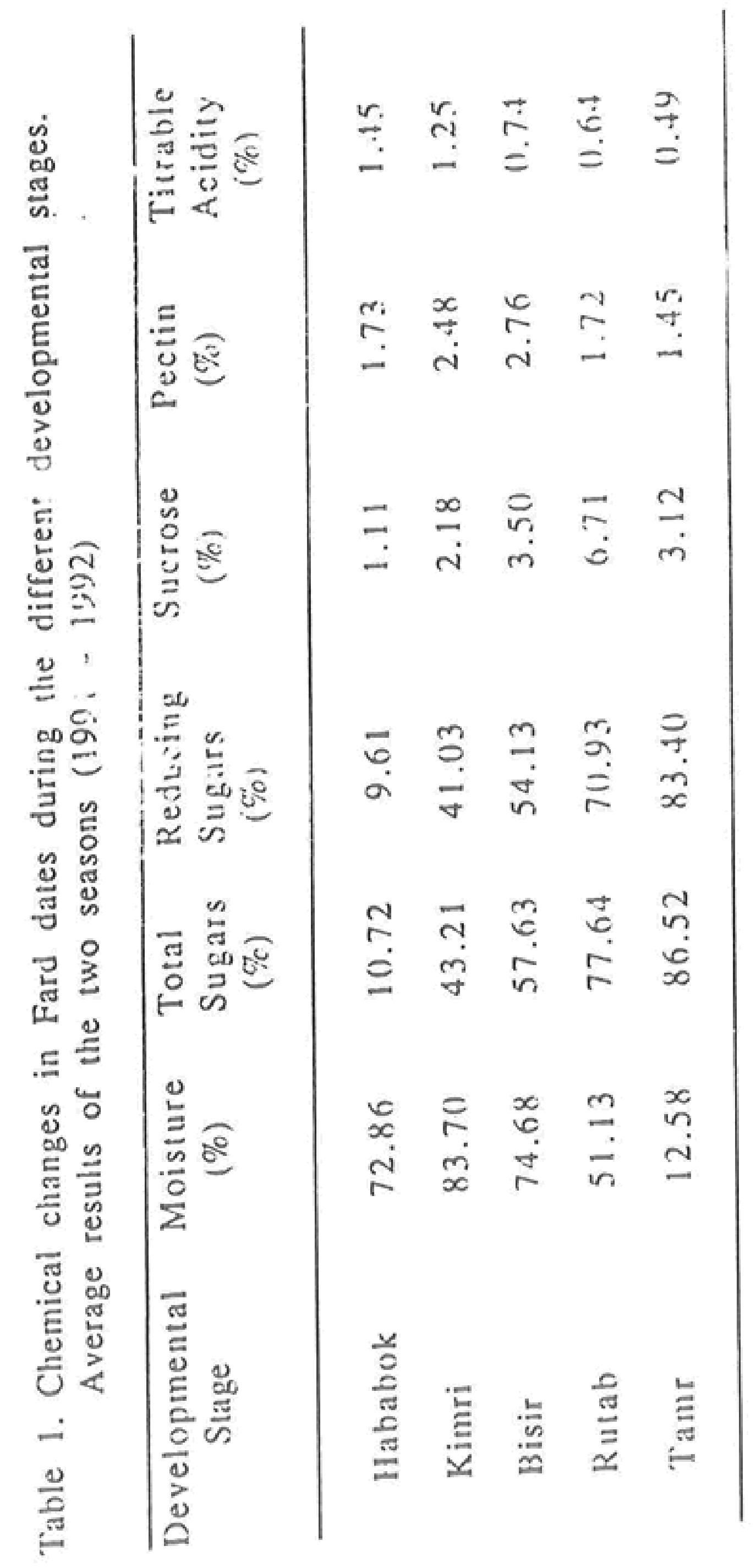


followed by $23 \%$ between Bisir and Rutab and $9 \%$ between Kimri and Bisir. These results are in agreement with those reported by Coggins and Knapp 1969, Hussein et al. 1976, Sawaya et al. 1983 and Basha et al. 1988.

b. Sugars : Total and reducing sugars increased progressively with maturation stages. The highest concentrations were in Tamr followed by Rutab and the least were in Hababok. The highest increase in total and reducing sugars was between Hababok and Kimri $32.5 \%$ and $31.1 \%$, respectively) and the lowest was between Rutab and Tamr ( $8.9 \%$ and $12.57 \%$, respectively). The increase in total sugars was always greater than the increase in reducing sugars except between Rutab and Tamr. This exception coincided with the only reduction in sucrose, signalling an increased activity of invertase enzyme. The results are in agreement with those obtained by Vinson 1911, Hass and Bliss 1935, Ashmawi et al. 1955, Sakri et al. 1975, Mougheith et al. 1976, Hussein 1982, Sawaya 1983, Saad et al. 1986 and Basha et al. 1988. Reducing sugars are greater than sucrose throughout the developmental stages, indicating that Fard cultivar is of the soft type as defined by Hass and Bliss 1935, Cook and Furr 1953, Mougeith 1976 and Rouhani and Bassiri 1976.

c. Pectin : Pectin percentage increased from Hababok to Bisir then began to decrease. The decrease rate was greater between Bisir and Rutab than between Rutab and Tamr $(1.04 \%$ and $0.27 \%$, respectively) indicating that pectinase enzymes are more active in the period between Bisir and Rutab. This confirms the results reported by Al-Jasim and Al-Delaimy 1972 and Bukhar et al. 1987. Reduction in pectin content is related to the softening of fruit towards ripening (Coggins and Knapp 1967, Hassegawa et al. 1969).

d. Acidity : As shown by data in Table (1) there was a continuous reduction in acidity from Hababok to Tamr. These reults are in agreement with those reported by Hass and Bliss 1935, Khalifa 1973, Al-Azzooni 1975, Rouhani and Bassiri 1976, and Mougeith 1976 who worked on different cultivars. Mougeith 1976 who worked on different cultivars. However, Basha et al. 1988, reported that acidity increased in Tamr. Reduction in acidity was associated with an increase in reducing sugar. This is supported by Rugg 1948, who reported that high acidity hinders ripening. 


\section{Effects of Pollination Methods}

Data in Table 2 show that total and reducing sugars in Bisir fruits produced by the three pollination methods followed similar patterns. The 1991 Bisir fruits from trees pollinated by the LBR method contained significantly higher amounts of total and reduccing sugars compared to those from trees pollinated by the HAND and MAC dusters. This significant effect was not observed in 1992. The significant higher sucrose in Tamr of 1992 can be attributed to delayed maturation (Shabana et al. 1975, Bukhar et al. 1987 and Rajab et al. 1956). Average pectin content in LBR Rutab and acidity in LBR Hababok were significantly higher than those in MAC fruits. No significant difference was observed between the effects of MAC and HAND on pectin in Bisir, Rutab and acidity in Hababok stages. The lack of consistency in these changes leads to believe that variations in the effect of pollination methods on sugar, pectin and titrable acidity are more likely influenced by the alternate bearing phenomenon. The influenced by the alternate bearing phenomenon. The significant effect of the pollination method observed during Hababok, Bisir, Rutab and Tamr stages could be related to the fast increase in the size of the fruit (Al-Bakr, 1972) as well as to a slight increase in dry weight, sugars, and titrable acidity (Basha et al., 1988).

\section{Effects of Pollen Dilution Ratio}

Pollen dilution had no significant effect on the tested parameters during the Kimri stage. Data in Table 3 show that total and reducing sugars followed similar trends : during the Bisir stage of 1991, LBR fruits contained the highest percentages than 1:5 ratio and the least percentages were in fruits produced by 1:7 and 1:9 ratios. Considering the mechanically applied pollen, the higher the concentration of pollen the higher the total and reducing sugars percentages were observed in Bisir and sucrose in Hababok of 1991 fruits. This significant effect could not be detected in 1992. Instead, significant differences were observed in sucrose in Bisir, Rutab and Tamr of 1992. During the Bisir stage, the 1:9 ratio produced fruits with significantly higher sucrose percentages than those produced by 1:5 and 1:7 ratios. The highest sucrose percentages in Bisir and Rutab produced by the 1:9 ratio in 1992 corresponded to the lowest total and reducing sugar percentages in the Bisir of 1991. They also coincided with the lowest pectin amounts in the Bisir and Rutab of the combined 


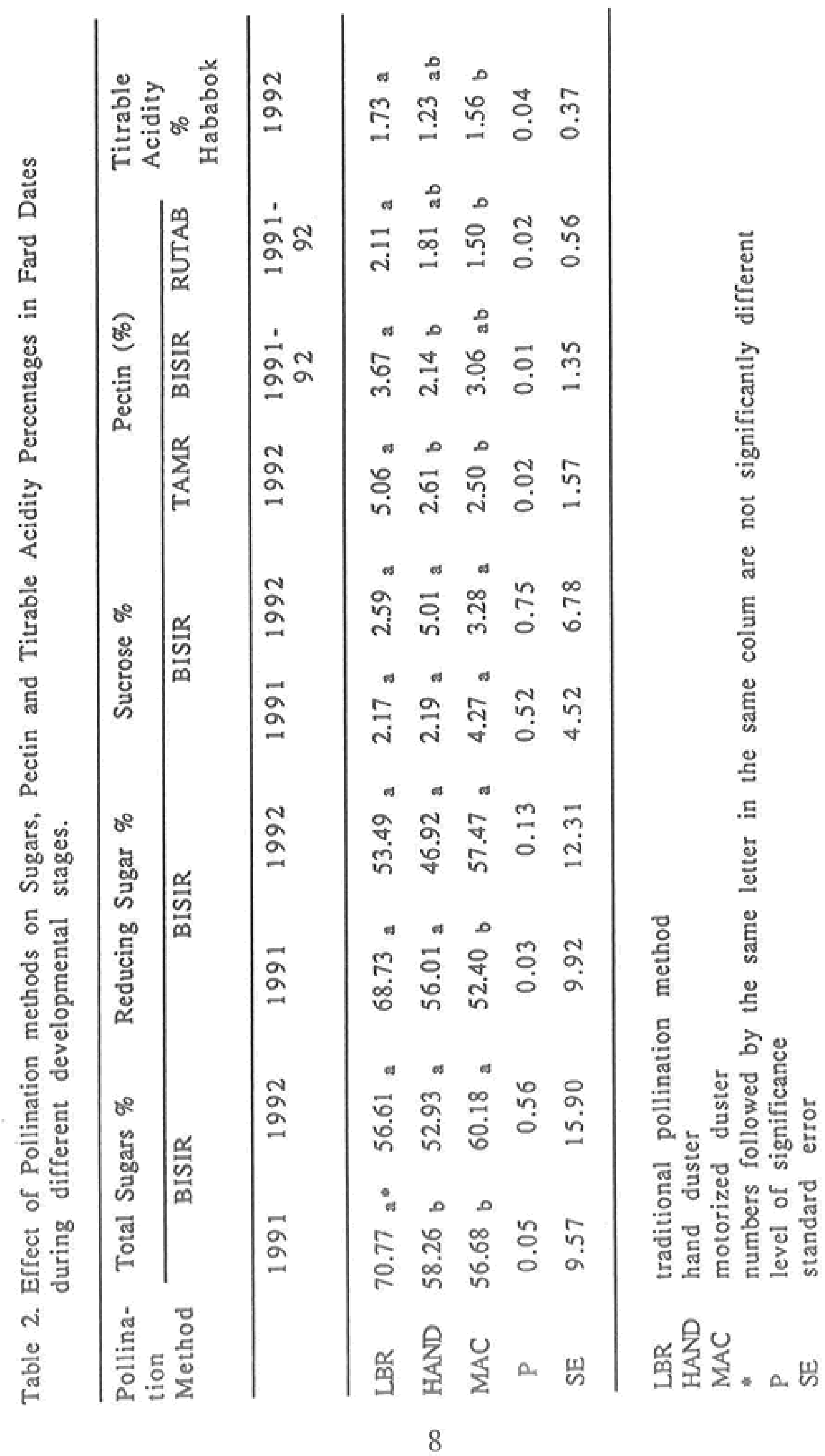




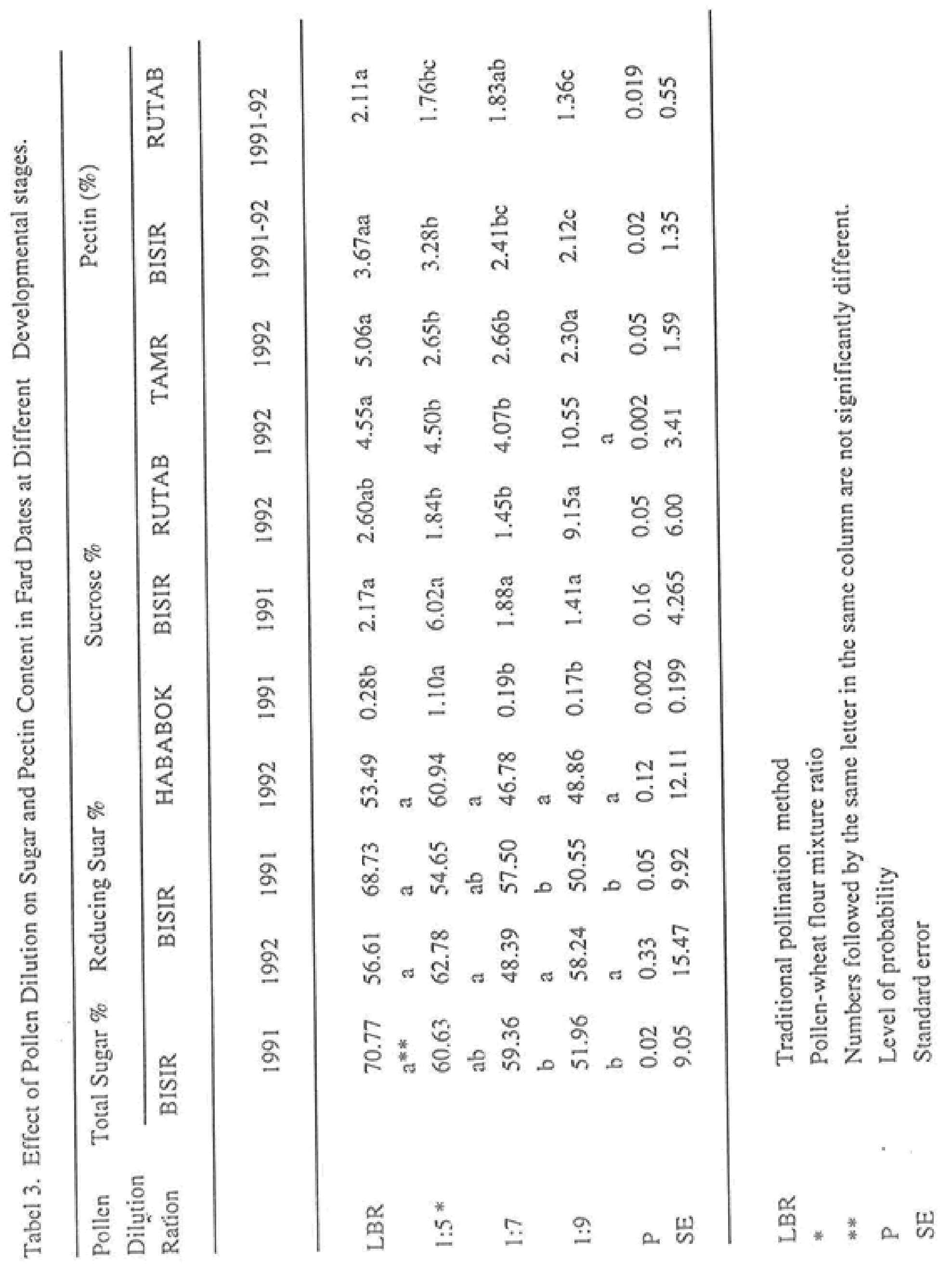


two years' results. Such changes in sugars and pectin contents are probably related to the changes which have occurred in the activity of ivertase and pectinase enzymes. It seems that the lower the pollen-flour ratio the higher the activity of pectinase (low pectin) than ivertase (high sucrose) in the Bisir and Rutab stages.

The relationship between enzymatic activity and pollen dilution requires further investigation as it appears to be the most probably reason behind the observation of insignificant effect on total and reducing sugars in the Bisir of 1992. Comparable results were reported by El-Kassas and Mahmood(1986) on Zagloul date cultivar. Insignificant difference was observed in reducing sugar during the two years of the experiment and in non-reducing sugar and titrable acidity in the first year.

\section{Effects of the Interaction Between Pollination Method and Dilution Ratios}

Data in Table 4 show that in 1992, total sugars content increased with the increase in pollen concentration, when the motorized duster was used. With the HAND duster, ratio 1:7 produced the highest total sugars followed by ratio 1:5. The least percentage was in fruits produced by the 1:9 ratio. The highest reducing sugar percentages in Bisir of 1992 was in fruits produced by MAC 1:5 and 1:7 and by HAND 1:5. It coincided with the highest pectin percentages (MAC 1:5 and 1:7), whereas the lowest pectin percentage coincided with the lowest reducing sugars in fruits produced by HAND 1:7.

Pectin content followed similar trends in Bisir and Rutab stages, but in every individual treatment combination, Bisir contained almost double the amount of pectin in Rutab except in HAND, 1:7.

It appears that the variations in pectin content in Bisir and Rutab might have stimulated the subsequent changes in total and reducing sugars of Bisir during 1992 and 1991, respectively, and in sucrose in the Rutab of 1991. Consequently, no significant difference was observed under these conditions. Significant differences were observed in sucrose content in Rutab fruits of 1992 but not in those of 1991. Fruits produced in 1992 by low pollen concentration (MAC, 1:9 and HAND, 1:9) had higher sucrose contents than those produced by higher pollen concentration (MAC, 1:5, 1:7 and HAND 1:5). 


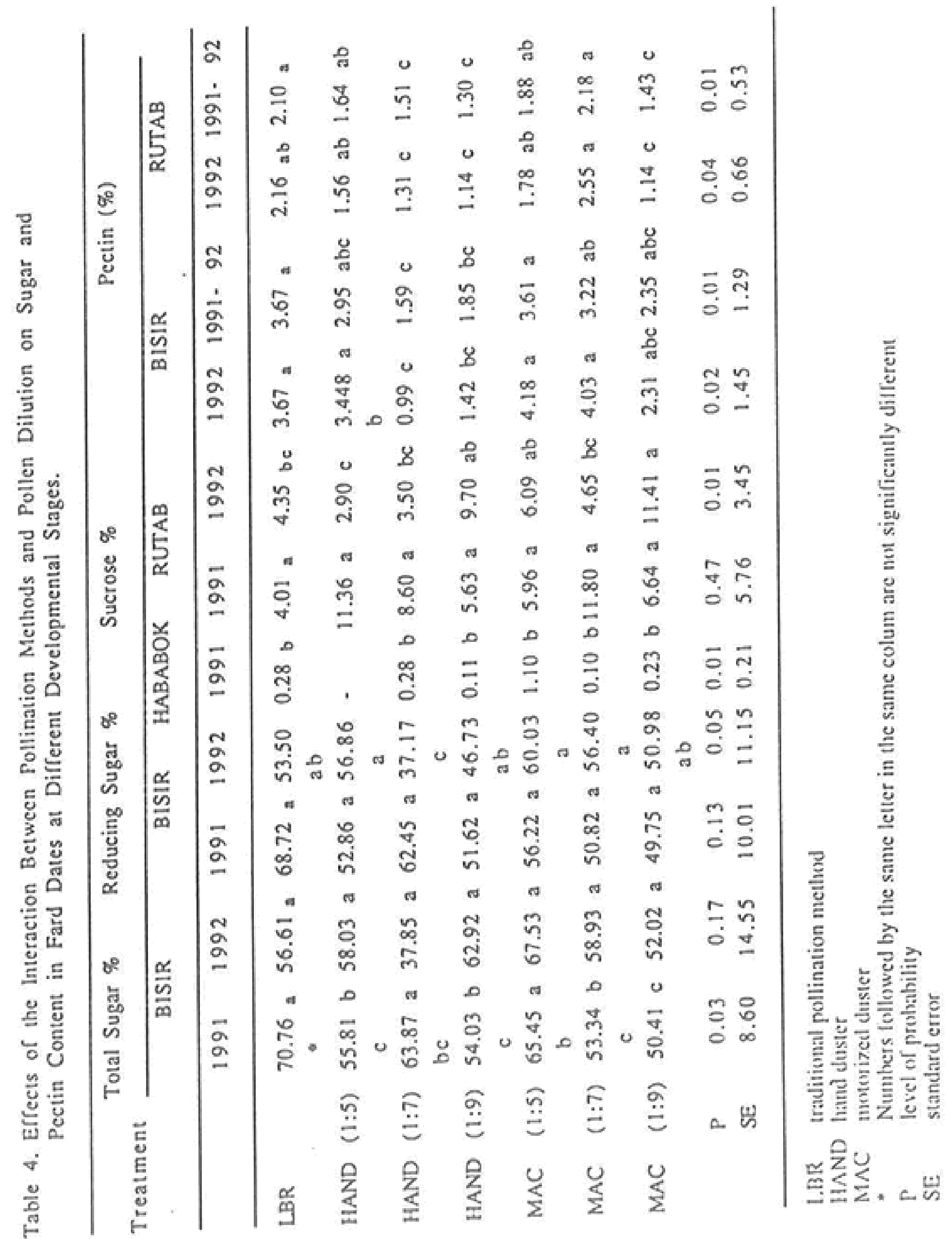


According to data shown in Table 5, high concentrations of pollen seem to be associated with high pectin conten, high total sugars had high reducing sugars in Bisir 1991 fruits. But in Rutab, high pollen concentration is associated with high pectin and lower sucrose in 1992 and high surcose in 1991 (Table 5). It is more likely that pectinase enzyme is more active in Rutab than in Tamr and that invertase is more active in Rutab. Apparently, these changes seem to be influenced by the effect of the amount of pollen reaching the pistil on the activity of invertase and pectinase enzymes during the different developmental stages of the fruit. The total amout of pollen received by the flowers varies with the method of application.

\section{CONCLUSION}

No clear significant differences were observed in the effect of pollination methods or pollen concentration on total and reducing sugars, sucrose, pectin, and titrable acidity. Variations in the effect of pollination methods on sugar, pectin and titrable acidity are more likely to be influenced by the alternate bearing phenomenon. Although pollen concentration had no significant effect on the chemical constituents in the Kimri stage, variations in sugars and pectin contents in the other four stages are probably related to the changes which occurred in the activity of invertase and pectinase enzymes in relation to the amount of pollen received by flowers. This phonomenon needs further investigation.

The results of this experiment did not give any clear evidence of the superiority of any of the pollination methods over the others. This is very encouraging towards the use of mechanized pollinators either hand operated (HAND) or motorized (MAC) as a substitute for the traditional pollination method. Further investigation is, however, required to make these devices fully operational in the hands of local farmers.

\section{ACKNOWLEDGEMENT}

The authors would like to thank all the personnel of the Ministry of Agriculture and Fisheries for their extensive and valuable help, particularly Dr. N. D. Benjamin and Mr. Mohamed Al-Marzougui. We are also indebted to Dr. Foerster, Head of the Department of Agriculture Mechanization at Sultan Qaboos 


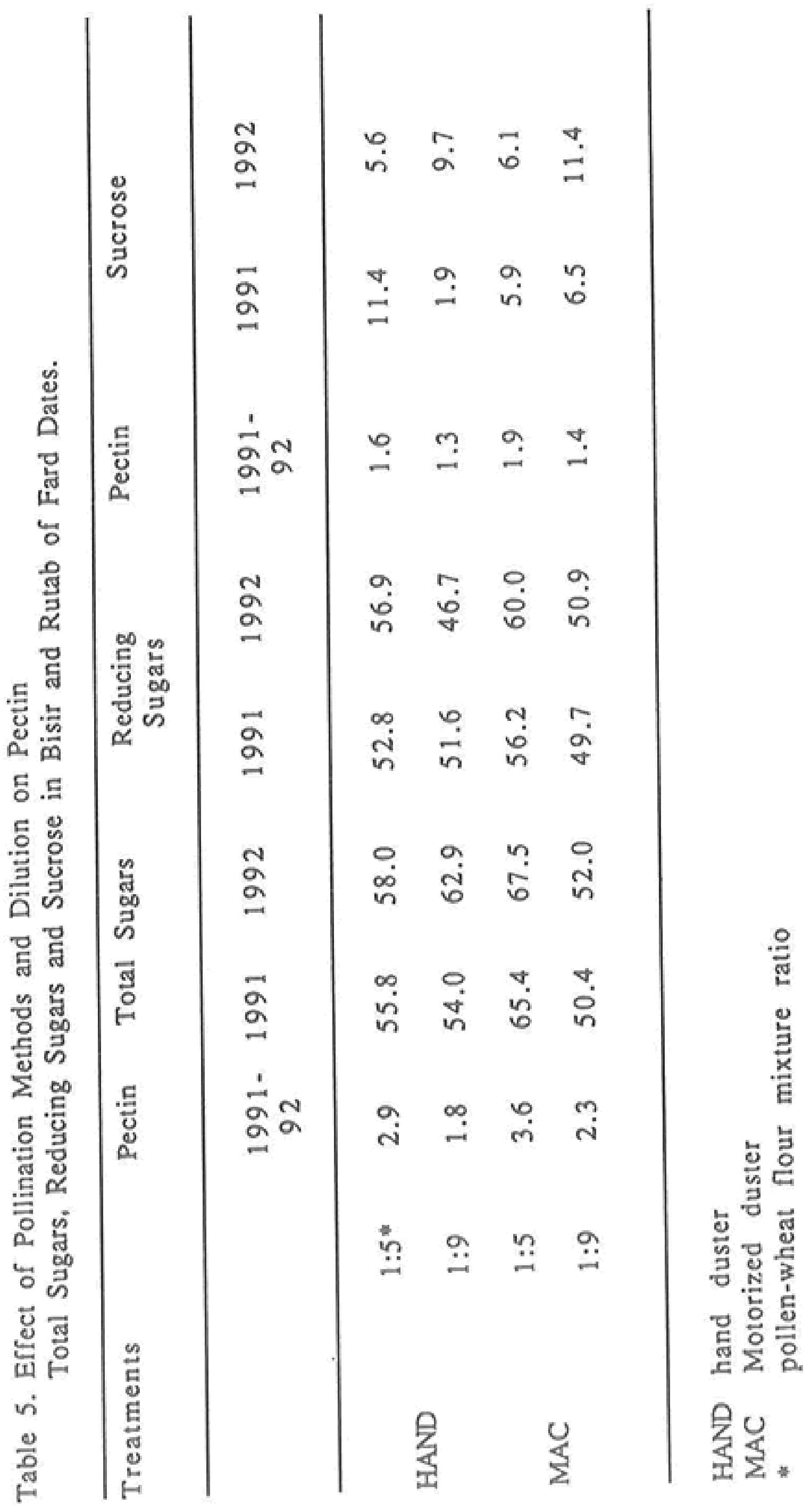


University (Oman), for his help and advice.

\section{REFERENCES}

Alexander, D. E. W. 1952. A method of pollinating dates. Date Grower's Inst. Rpt. 29:20.

Al-Jasim, H. A. and K. S. Al-Delaimy, 1972. Pectin esterase activity of some Iraqi dates at different stages of maturity. J. Sci. Food Agri. 23:915-917.

AOAC, 1975. Official Methods of Analysis. Association of Offcicial Analytical Chemists. 12th ed. Washington, D. C.

AOAC, 1984. Official Methods of Analysis. Association of Official Analytical Chemists. 13th ed. Washington, D. C.

Ashmawi, H., H. Aref, A. El-Hussein, 1955. Chemical changes in Samani dates during growth and ripening. Bull. Fac. Agr., Cairo University, 60:3-13.

Bukhar, V. T., B. A. Abdul Nour, V. F. Nouri, 1987. Physical, chemi cal changes in dates during ripening with special references to pectic substance. Date Palm J. 5(2):199-207.

Coggins, C. W. Jr. and J. C. Knappe, 1969. Growth, development and softening of the Deglet Noor date fruit. Date Grower's Inst. Rept. 46:11-14.

Cook, J. A. and J. R. Furr, 1953. Kinds and relative amounts of sugars and their relation to texture in some American grown dates. Proc. Amer. Soc. Hort. Sci. 61:286-292.

El-Azzoni, M. M., M. T. Kabell, E. L. Baker, and M. H. Abdelrah man, 1975. Development changes in fruit characters and maturity determination of two date varieties. Annals Agr. Sci. Moshtoher. 4:221-234.

El-kassas, Sh. E. and H. M. Mahmoud, 1986. The possibility of pollinating date palm by diluted pollen. Proceedings of the 2nd Symposium on the date palm. King Faisal University, Al-Hassa, Saudi Arabia. 317-321. 
Furr, J. R. and A. Hewitt, 1964. Thinning trials on Medjool date Pollen dilution and chemicals. Date Grower's Inst. Rpt. 41:1718.

Hamood, H. H., E. A. Mawlood, 1986. The effect of mechanical pollination on fruit set, yield and fruit characteristic of date palm. Zahdi Cultivar. The Date Palm J. 4(2):176-184.

Hass, A. K. C. and D. E. Bliss, 1935. Growth and Composition of Deglet Noor dates in relation to water injury. Hilgardia, 9:295-344.

Hessegawa, S., V. P. Maier, H. P. Kaszykki and J. K. Crawford, 1969. Polygalacturonase content of dates and its relation to maturity and softness. J. Food Sci. 34:527-529.

Hussein, F., S. Moustafa, F. El-Samirae and A. El-Zeid, 1976. Studies on physical and chemical characteristics of eighteen date cultivars grown in Saudi Arabia. Indian J. Hort. 33:107113.

Hussein, F. A. and El-Zeid, 1978. Physico-chemical properties of some Saudi Arabian date cultivars. Min. of Agr. and Water Res. Dev. Department. Kingdom of Saudi Arabia.

Hussein, F., D. I. Dahshan, S. I. Gaffar and I. A. Mousa, 1982. Evaluation of some seedling date palms grown at Ismailia Governorate Fac. Agric. Zagazig Univ. Bull. 506.

Khalifa, A. S., 1973. Physiological studies on maturity, ripening, handling and storage of date, Ph. D. Thesis, Hort. Dept., Fac. Agric. Cario Univ.

Less, R. 1975. Food Analysis. Leonard Hill Books, London.

Mohamed, S., H. R. Shabana and E. A. Mawlod, 1983. Evaluation and indentification of Iraqi date cultivars; Fruit and characteristics of fifity cultivars. Date Palm J. 2 (1):27-55. 
Monciero, A., 1950. Contribution to the study of date palms. Annals of the Inst. of Agro. and Research Services in Algeria; General Inspector of Agriculture. Algeria. (translated from French).

Mougeith, M. G., 1976. Comparative study of fruit development, quality and characteristics at harvest of some Egyptian date cultivars. Annals of Agr. Sci. Moshtohor, Egypt. 5:177-193.

Preston, R. D., 1964. Pollinating dates by air plane. Date Grower's Inst. Rpt. 41:24.

Pretson, R. D., 1965. In panel discussion of labor saving devices in pollinating dates. Date Grower's Inst. Rpt. 42:6-7.

Rajab, M. H., A. and Seadky, 1956. Studies on the Egyptian dates. Two chemical changes during development and ripening of six varieties. Food Tech., 10:407-410.

Rouhani, I. and A. Bassiri A., 1976. Changes in the physical and chemical characteristics of Shahani dates during development and maturity. J. Hort. Sci. 51:489-494.

Rugg, G. L., 1946. Compositional changes in the date fruit during growth and ripening. U.S.D.A. Tech. Bull. 910 pp51.

Rugg, G. L., 1948. Acidity in relation to quality in the date fruit. Date Grower's Inst. Rpt. 25:32-33.

Sakri, F. A., N. D. Benjamin and N. J. Enwa, 1975. Realtion of invertase activity to sucrose content of date fruit during different developmental stages. Bull. Col. Sci. Univ. Baghdad. 16 (2):225-253.

Sawaya, W. N., H. A. Khatchadarian, J. K. Khalid, W. M. Safri, and A. Al-Shalhat, 1982. Growth and compositinal changes during the various developmental stages of some Saudi Arabian date cultivars. J. Food Sci. 47(5):1489-1492.

Sawaya, W. N., J. K. Khalid, W. M. Safri and A. Al-Shalhat, 1983. Physical and chemical characteristics of three Saudi dater cultivars at various stages of development. Can. Inst. Food Sci. Tech. J. 16:87-92. 
Shabana, H. R., K. S. Jawad, N. D. Benjamin and B. A. Al-Ani, 1975. Physico-chemical changes during different stages of ripening and determination of the depressed period of development in the date fruit. Third International Palm and Date Conf., Baghdad, Iraq.

Vinson, A. E., 1911. Chemistry of ripening of the date. Ariz. Expt. Sta. Bull. 66:403-435.

Vis, E. G., R. M. Perkins and G. K. Brown, 1971. Mechanical pollination experiments with the Deglet Noor date palm. Date Grower's Inst. Rpt. 48:19-22.

Yousif, A. K., N. D. Benjamin, A. K. Kado and S. M. Ali, 1982. Chemical Composition of Iraqi Date. Date Palm J. 1(2)285294. 
تأثيـر طرق التلقيح وتفخفيف هـبوب اللقاح على بعض المكونات الكيميائية خلال مراحل تطور ثمار الفرض .

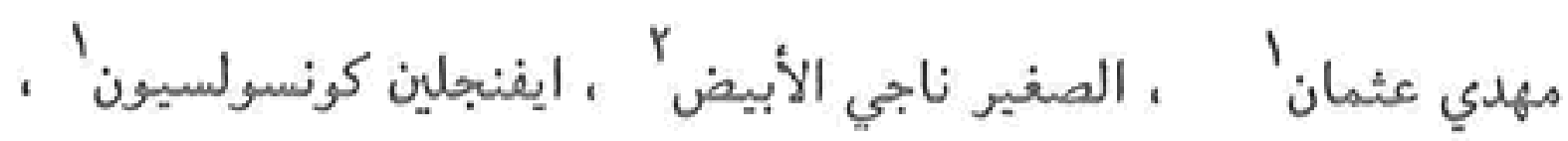

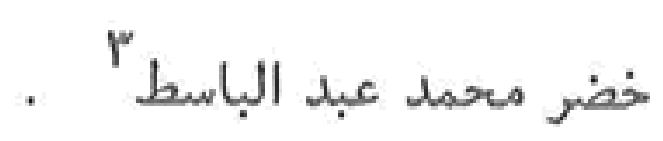
ا قسم علوم النبات ، كلية الزراعة r ب بم الميكنة الزراعية ، كلية الزراعة

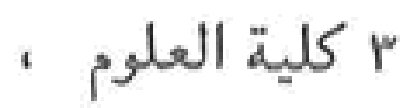
جامعة السلطان قابوس ، مسقط ، عُمان

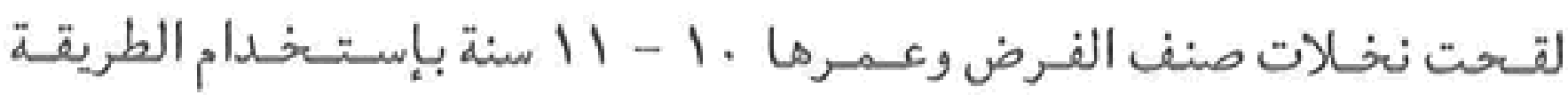

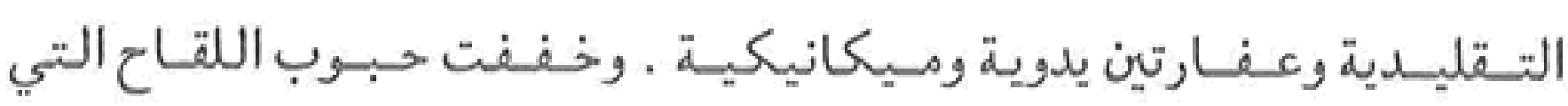
أستعملت مع العفارتين بنسب : 1 : 0 ، 1 : 9 . حددت النسب المئوية

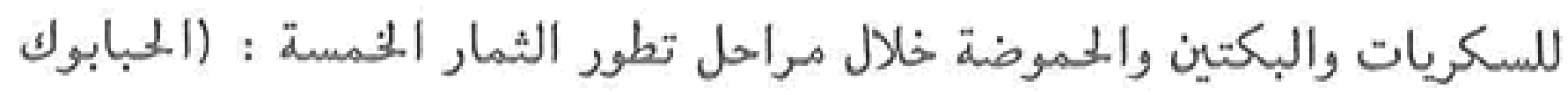
الكمري ، البسر ، الرطب ، التمر ) لموسمي 1991 و 1994 ـ بينت نتائج التجربة عدم وجود فروقات معنوية خلال مرحلة الكمري فى أي الكي

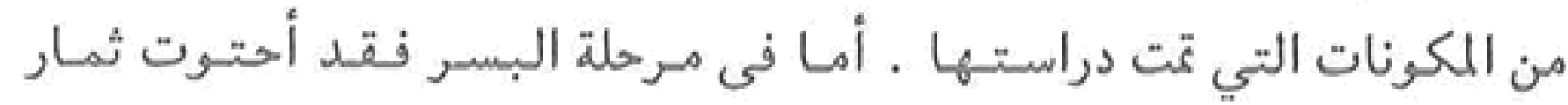

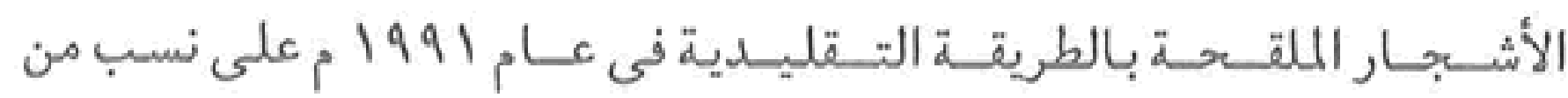

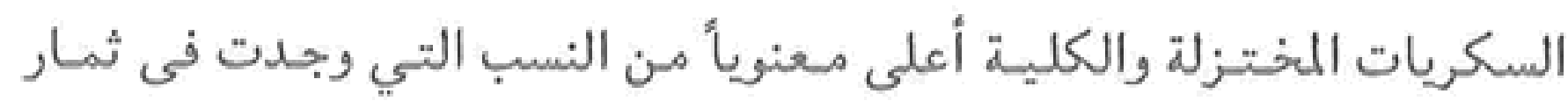

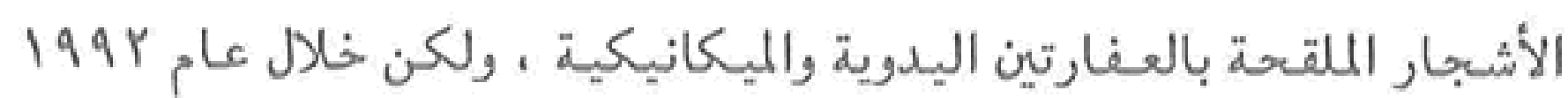
فأن ثمار الأشجار الملقحة بالطريقة التقليدية فقد أحتوت في مرحلتي 
الحبابوك والتمر على نسب أعلى من الحموضة والسكروز على التوالي ـ لقد

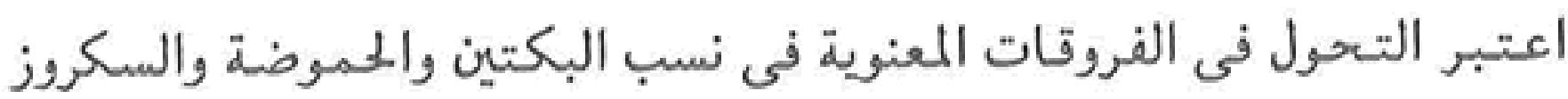

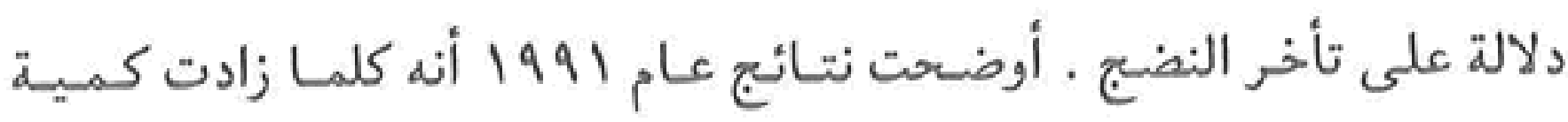

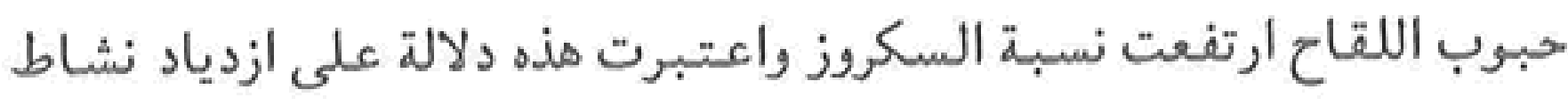

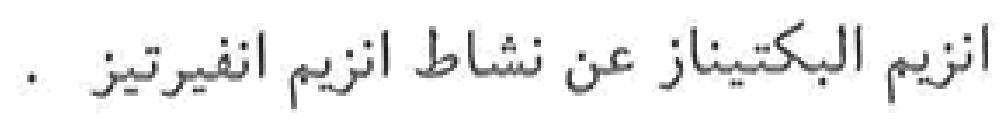

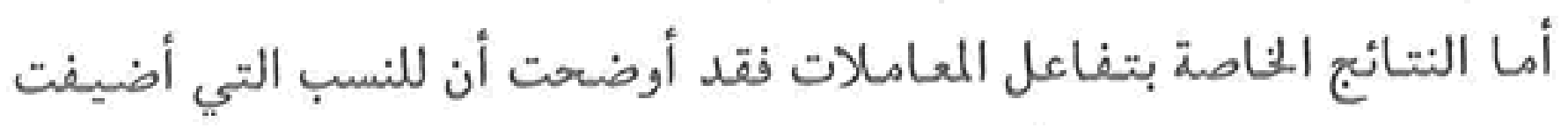

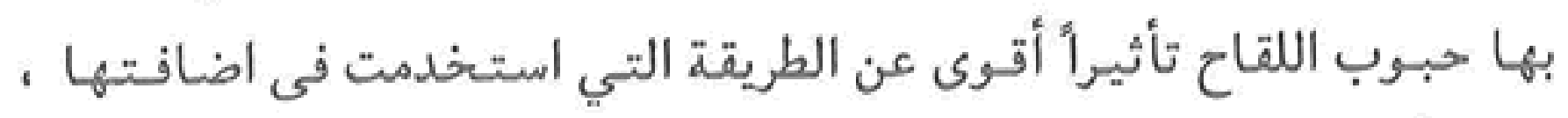

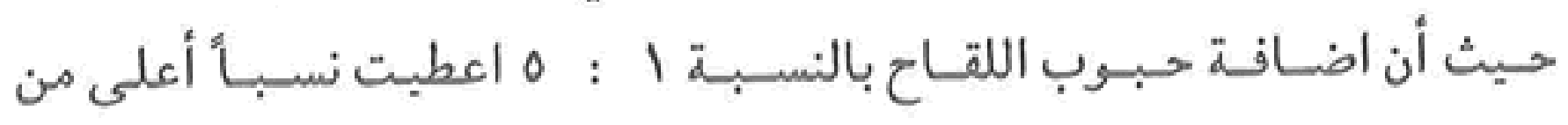

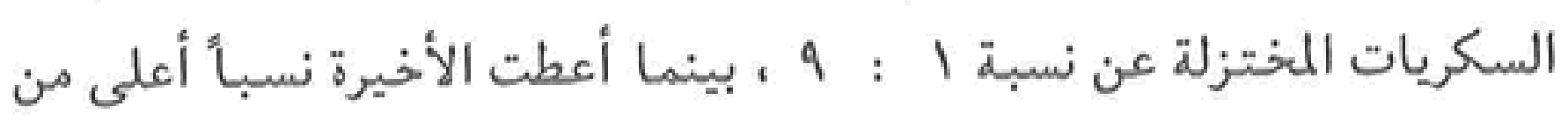

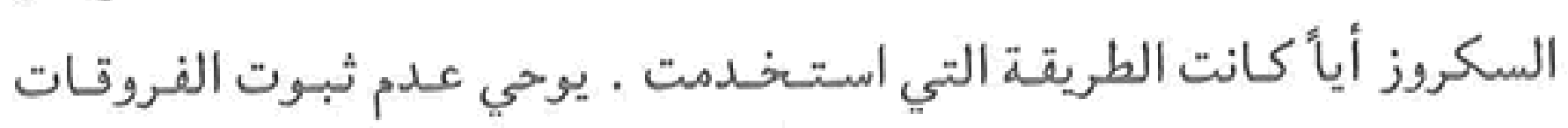

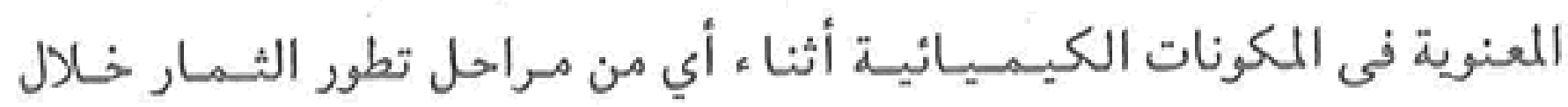

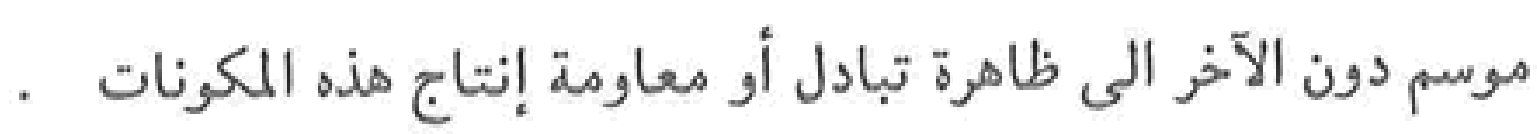

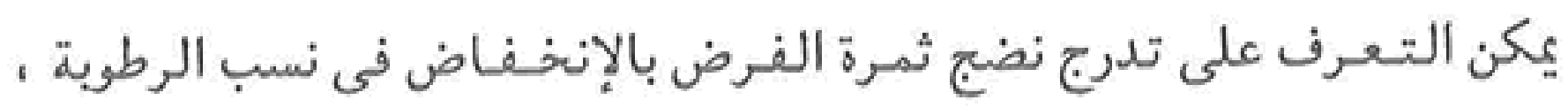

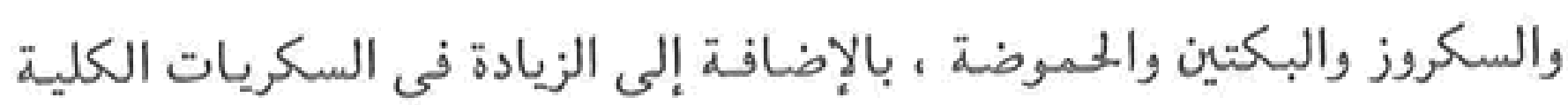

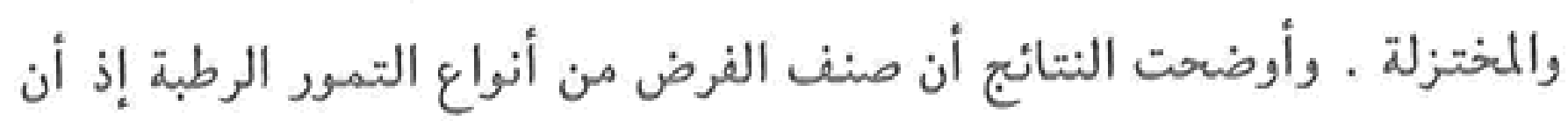

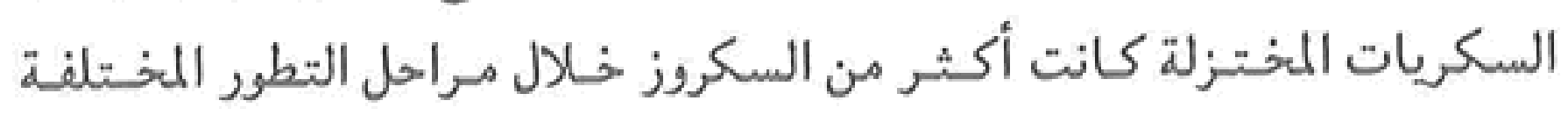
· للثمار

كللات مفتاهية : المعاومة ، الميكنة ، التلقيح ، تخفيف حبوب اللقاح. 